\title{
California takes the gloves off
}

\section{San Francisco}

AFTER watching the repeated failure of California's efforts to win multi-milliondollar federal science projects, the state's legislature last week launched its first nonpartisan lobbying organization to persuade Washington to invest in the state. The California Institute, to be led jointly by the state's new governor, its senators and senior congressional representatives from both parties, will replace the fragmented lobbying efforts now carried out by cities, counties and party leadership.

California has lost bids for several major research projects in recent years. In 1986 , in an especially embarrassing decision, earthquake-prone California was passed over in favour of New York state as the site of the Earthquake Engineering Research Center. In January 1988, Austin, Texas, landed Sematech, the national semiconductor manufacturing technology consortium. Later that year, Texas won the $\$ 8,000$-million Superconducting Super Collider. Those incidents were the "final straws", says Randall E. Davis, acting executive director of the California Institute.

Planners of the non-profit, privately SATELLITE ENGINEERING

\section{Surrey spreads its wings}

\section{London}

THE University of Surrey is spending £2 million on a new research centre to consolidate its European lead in microsatellite engineering. The centre, now being designed, will house 100 researchers.

The small, relatively cheap satellites which the Surrey group produces can fly low-cost space science experiments and be used for communications. The group's fifth satellite, UoSAT-F, is due for launch in May, and will carry equipment to detect cosmic particles, to correlate these events with the performance of the craft's microelectronics. The satellite will also relay electronic mail messages at low cost, providing a badly needed service for relief workers in developing countries, and will test the in-flight performance of a range of solar cell designs.

Microsatellite engineering is still a small field in Europe, but in the United States, both the National Aeronautics and Space Administration and the Department of Defense (DoD) are showing interest in small (though not necessarily cheap) satellites. DoD has recently given its backing to the Pegasus launch vehicle project - a microsatellite-launching rocket that can be launched from high in the atmosphere, carried by a B-52 bomber. Peter Aldhous funded institute say science and technology will be among its priorities. In Governor Pete Wilson's first weeks in office, he has already indicated his interest in attracting the International Thermonuclear Experimental Reactor (ITER) to the state. San Diego has been chosen by the US Department of Energy as the site it will propose for the international project's design efforts if the United States formalizes its decision to join the coalition.

Although the institute's agenda will not be decided until its board of directors is named, Davis says the group will probably pursue ITER. Davis believes the reactor's potential long-term dividends to California are very important.

The institute will also pursue smaller projects and more subtle funding and regulatory changes. For example, the team is

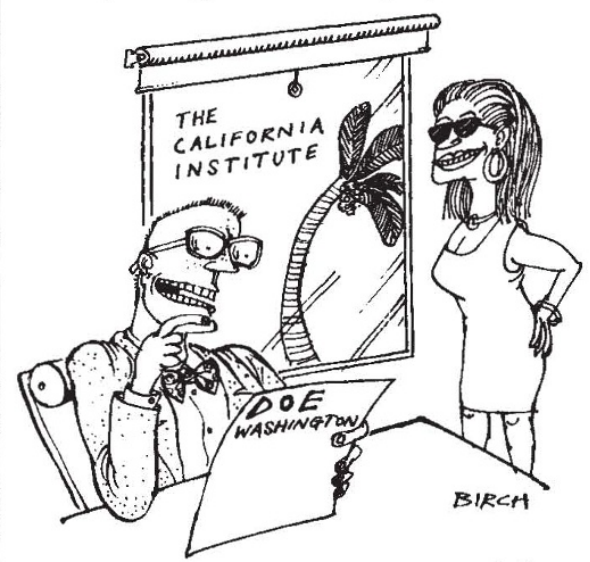

Well, at least we've persuaded them to come here for their vacations...

examining the funding practices of the National Science Foundation and the Defense Advanced Research Projects Agency. It intends to consider how best to pursue smaller grants from those organizations, including grants that may require matching local funds. The institute will also encourage nationwide programmes, such as the proposed National Fiber Optics Network for supercomputers, which would especially benefit California's high-technology businesses.

In some ways, California already has more political influence than any other state. The California congressional delegation, for instance, is already the nation's largest and in 1993 will swell to 52 members - nearly one in eight of the 435member House of Representatives. But many other states have maximized their influence by forming non-partisan lobbying organizations, such as the 19-state Northeast-Midwest Institute, the ninemember Sunbelt Caucus and individual institutes of Texas and Illinois. Now California will follow suit, and the others should watch out.

\section{Emergency shutdown of oldest reactor}

\section{Tokyo}

A leak in the primary cooling system of one of Japan's oldest nuclear power reactors triggered operation of an emergency cooling system last Saturday (10 February) that shut down the reactor. This is the first time such an emergency has occurred in Japan and it has added new fuel to the nation's growing anti-nuclear movement.

The Mihama nuclear plant on the Japan Sea coast where the accident occurred is Japan's first commercial power station and is more than 20 years old. The leak last week developed in the number two reactor which began operation in 1972 .

According to initial reports, highpressure primary cooling water of the $500,000-\mathrm{kW}$ pressurized light water reactor leaked out of thin pipes in the heat exchanger into the secondary steam system that drives the plant's electrical generator. A rapid drop in pressure of the primary cooling water automatically activated the emergency cooling system, which pours large amounts of water into the reactor to prevent a meltdown.

This is not the first time such a leak has occurred in the ageing plant. Cracks have been detected in the $2.2-\mathrm{cm}$ diameter tubes of the primary cooling system of the reactor on numerous occasions in the past and hundreds of the more than 7,000 tubes in the primary cooling system have been bypassed to prevent leaks. But this is the first time that a leak has triggered the emergency cooling system. The pressure in the primary system dropped from 157 atmospheres to $\mathbf{1 2 8}$ atmospheres in ten minutes and local government officials estimate that about 20 tons of highly radioactive primary coolant leaked into the secondary system.

Officials of Kansai Electric Power Company, which operates the plant, and the local and central government say that no radioactivity has leaked into surrounding local environment. But the accident has sparked considerable local and nationwide concern.

The Mihama plant sucks a river of water out of Mihama Bay for its cooling system and the water is pumped straight back into the bay which has a thriving fish farm industry.

Japan's anti-nuclear power movement, which since the Chernobyl disaster enjoys considerable support from housewives around the nation, has been quick to latch onto the Mihama accident, which they say demonstrates an inherent defect of pressurized water reactors.

The Nuclear Safety Commission met in emergency session on Monday to discuss the accident, but it had released no statement as Nature went to press.

David Swinbanks 